\title{
Sustaining old historic cities through heritage-led regeneration
}

\author{
S. Y. Said ${ }^{1}$, S. S. Syed Zainal ${ }^{1}$, M. G. Thomas ${ }^{2}$ \& B. Goodey ${ }^{2}$ \\ ${ }^{1}$ Faculty of Architecture, Planning and Surveying, \\ UiTM Shah Alam, Malaysia \\ ${ }^{2}$ Department of Planning, Oxford Brookes University, UK
}

\begin{abstract}
Old cities in the developing nations, including Malaysia, currently face intensified urban problems as a result of rapid economic development and population growth. The emergence of new townships at the edge of many historic cities in Malaysia has affected the significant identity of these places. Urban conservation is seen as an important element for urban regeneration scheme in most historic areas as the vibrancy of a heritage site is only significant when its original community remains. The study covers theoretical and practical aspects of conservation practice and regeneration initiatives of historic cities, relevant to Malaysia, taking into consideration social, cultural, political, economic aspects and stakeholders' aspirations. It seeks to explore whether the current practice facilitate in regenerating the economy of the areas to ensure the sustainable continuity of the local culture in the historic urban environment. Studies on Melaka and George Town reveal the importance of incorporating cultural, physical, economy and social factors in regeneration of these historic areas in Malaysia.
\end{abstract}

Keywords: heritage-led regeneration, quality of life, sustainable historic city.

\section{Introduction}

The word 'regeneration' has been a catchphrase in policy and planning for the past twenty years. There is no one definition of 'regeneration', and the term seems to have been appropriated by politicians, planners and managers in the cultural, social, architectural and construction sectors, as necessary to suit their changing agendas. Urban regeneration refers to the movement to improve the 
condition of urban quarters, mostly the dilapidated historic areas. The heritageled urban regeneration involves inducing life into decaying assets and developing the future potential of a neighbourhood. It is a 'comprehensive and integrated vision and action which leads to the resolution of urban problems and which seeks to bring about a lasting improvement in the economic, physical, social and environment condition of an area that has been subject to change' [1].

Regeneration basically is a planning method of renewing, enhancing and integrating the old historic environment to a new, modern, economically thriving environment. Urban regeneration aims towards the transition of the physical, social, environmental and economic conditions to achieve a better quality of life by promoting economic and social renewal and most importantly to create opportunities for employment and income earning. It is a move towards a more comprehensive form of policy and practice which emphasizes integrated treatment of the urban area $[1,2]$.

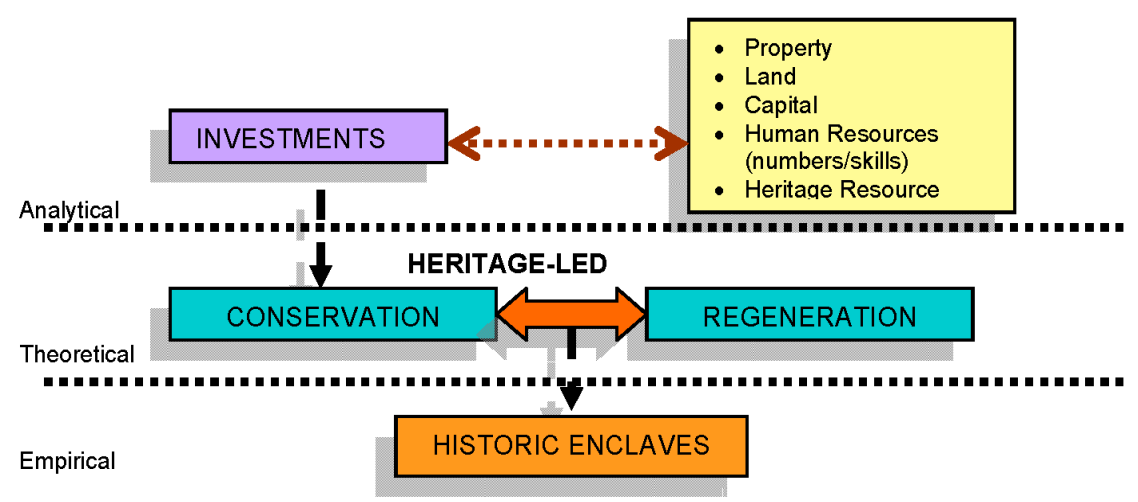

Figure 1: Theoretical framework for heritage-led urban regeneration.

Beside the snowballing effect on the investment towards heritage, the sustainable heritage-led regeneration concept promotes six elements of investments towards conservation in terms of property, land, capital, human resources, heritage resources and political commitment (Figure 1). Better condition of historic areas resulting from the conservation work carried out is believed to support the regeneration of the area as a whole (Table 1). The profit from regeneration would provide capital for more conservation activities. This cycle is an example of sustainable heritage-led urban regeneration model.

\subsection{Social and cultural value}

Social value is associated with places that people perceive as sources of identity, distinctiveness, social interaction and coherence. Social value is not usually recognised by those who share them, but may be articulated only when the future of a place is threatened [3]. 'Sociocultural values are the traditional core of conservation - values attached to an object, building, or place because it holds 
Table 1: Heritage-led regeneration: elements of investment on conservation that support regeneration.

\begin{tabular}{|c|c|c|}
\hline $\begin{array}{c}\text { Elements of } \\
\text { investment }\end{array}$ & Conservation & Regeneration \\
\hline Property & $\begin{array}{l}\text { In the form of built form, buildings or } \\
\text { monuments that are allowed for } \\
\text { conservation. }\end{array}$ & \multirow[t]{2}{*}{$\begin{array}{l}\text { Better condition of buildings and } \\
\text { streetscape suitable for modern } \\
\text { lifestyle. }\end{array}$} \\
\hline Land & $\begin{array}{l}\text { The areas and components of historic } \\
\text { cities that needed to be improved. }\end{array}$ & \\
\hline Capital & The amount of money invested. & $\begin{array}{l}\text { More investment attracted by the } \\
\text { schemes. }\end{array}$ \\
\hline $\begin{array}{l}\text { Human } \\
\text { Resources }\end{array}$ & $\begin{array}{l}\text { The number of the local workforce and } \\
\text { local skilled worker available. }\end{array}$ & Job creation. \\
\hline $\begin{array}{l}\text { Heritage } \\
\text { Resources }\end{array}$ & $\begin{array}{l}\text { The presence of valuable heritage in the } \\
\text { area. }\end{array}$ & $\begin{array}{l}\text { To encourage tourism. New } \\
\text { source of income for the } \\
\text { economy. }\end{array}$ \\
\hline $\begin{array}{l}\text { Political } \\
\text { commitment }\end{array}$ & $\begin{array}{l}\text { The commitment of the authority to } \\
\text { recognize the importance of conservation } \\
\text { work in their area. The commitment from } \\
\text { the authority to ensure the sustainability } \\
\text { of the heritage. }\end{array}$ & $\begin{array}{l}\text { The commitment from the } \\
\text { authority to ensure the } \\
\text { sustainability of the heritage. }\end{array}$ \\
\hline
\end{tabular}

meaning for people or social groups due to its age, beauty, artistry, or association with a significant person or event or (otherwise) contributes to processes of cultural affiliation' [4].

In a social context the importance of knowing the heritage and its value is essential in every society. Awareness about the history and glory of the past can help in nation building. A knowledgeable community is a community that understands the different aspects of values of their heritage.

Heritage is experienced and identity of a place. It has to be experienced for it to be heritage, moreover, it is not static or 'frozen in time' but an ongoing process that establishes and creates values and meanings [5]. All judgments about values are attributed to cultural properties and the credibility of the sources may differ from culture to culture, and even within the same culture. However, to respect decisions made by a community on its view of value and identity is crucial in judging the heritage properties within their cultural context [6].

Mutual respect for different heritage criteria is important to ensure the safeguarding of heritage in a multi-cultural society today. The respect for cultural and heritage diversity is important when dealing with communities and their heritage [7, 8]. It is a modest effort to determine the value and authenticity of heritage in a respectful manner. The cultural and spiritual values attached to places can emanate from local beliefs and teachings and generally are sensitive to modest changes in the character and particularly to the activities conducted there [3]. Shared cultural and spiritual beliefs can increase the value of the heritage assets and can be a driving force for their protection.

Old buildings represent memory of the place which provides emotional values to the area [9]. They provide important links between the past and the future which few modern buildings could achieve, even in a renewed environment. It is 
crucial to maintain the historic fabric of the proposed regenerated area in order to maintain its connection with the past.

\subsection{Economic value}

Historic buildings are parts of our heritage with strong physical evidence of our past. Larkham [10] quoted Cibrowski (1956) on the importance of architectural structures as the 'evidence of its economic and social development (for the entire nation). The works of architecture and town planning thus embody the history of the people that created them'. Therefore, conservation of historic buildings and areas would help to sustain the continuity of these values reenacting them to their glorious past.

The concept of urban conservation and regeneration of historic urban areas has led to the initiation of schemes to improve historic environment. Urban regeneration relies on past concept of physical regeneration of an area to a much more complex set of objectives including social, cultural and economic issues. 'The historic environment, instead of being a threatening area of dereliction is now an attractive focus for the local communities' [11].

The concept of 'conservation-led regeneration' or 'heritage-led regeneration' was the result of the change in policies for conservation and regeneration. Urban conservation policies were introduced in many historic cities to save the heritage and provide ways and mechanisms to sustain the cities by bringing opportunities for financial, social and cultural development. Old buildings represent past energy stored up in a usable form that is waiting to be enhanced and reused; therefore, building conservation is an honourable act in minimizing waste in a regeneration project in terms of money spent for new building and the amount of embodied energy released.

However, most of urban regeneration projects, urban regeneration has become an instrument of gentrification, socio-spatial segregation and social exclusion driven by neo-liberal urbanism politics occurred from market driven investments [12]. Fortunately, the World Bank has announced their interest in historic city regeneration. Among the key issues addressed are 'the importance of the historic cores that can be the pivot on which urban development should be anchored, in order to maintain and value the cultural identities of local communities' [13]. Successful repair of historic buildings usually attracts a higher value to that building and will generally attract further investment to the area and provides a much wider regeneration process, where the footprint is provided by the existing building and it is of merit in creating a robust and successful framework for further development.

\section{Heritage-led regeneration in Melaka and Penang}

Conservation of historic buildings has become part and parcel of urban regeneration schemes for Malaysian historic cities [14]. Unlike the UK, where regeneration is a resulted from evolution of a post-industrial society through an urban design approach, regeneration schemes in Malaysia are the result of the 
adaptation of the Western-styled approach to a local context, and more to a replication of urban regeneration principles from other countries. The background of education of the early group of town planners and architects in Malaysia in the early 1960s, mostly studied in the UK and they tend to bring their exposure to the UK Planning systems to contribute to the transfer of policy and urban design approaches in Malaysia.

Regeneration schemes that have been practised in Malaysia refer to introducing modern development to an area in order to initiate new means for economic activities, which will help to revive the area $[14,15]$. They are aimed towards the betterment of the social, cultural, environmental and economic characteristics of an area, in order to create better living conditions for its residents, through upgrading the infrastructure, providing funds and introducing modern public facilities [14-16].

Theoretically, regeneration in the context of Malaysia focuses on introducing activities conducive to develop a place, in order to gain social, economic and physical achievement. Nonetheless, the larger part of regeneration schemes in historic cities in Malaysia, places emphasis on the redevelopment of the areas which encompass modern development; whilst maintaining as much as possible of the historic fabric, in accordance with local acts and policy [14].

Nevertheless, Melakans and Penangites [17], have experienced different urban design approaches to the development of their historic cores. George Town, maintaining itself as a living city, focuses on providing modern infrastructure to the historic core, aiming to provide better living conditions for the occupants [15]. Regeneration schemes in Melaka stress economic benefits by providing tourism facilities to ensure inbound heritage tourism. Being associated with numbers of heritage buildings that form the identity of the historic city itself, the state government feels the need to provide good tourism facilities although, controversially, location chosen for these facilities are next to the historic buildings in order to make tourists feel and embrace the heritage.

\subsection{Regeneration of the Historic City of Melaka}

As part of the regeneration schemes, development activities in the Historic City of Melaka focus on the provision of new tourism facilities. Five star hotels and retail outlets are designed to cater for the increasing numbers of tourists. Heritage is the source for tourism activity and the basis of development of the historic core area. It is one of twelve sub-sectors for the tourism industry in Melaka.

After the proclamation of the World Heritage Site status, the number of tourists visiting Melaka increased greatly from 7.2 million in 2008 to 8.9 million in 2009, a surplus over the target of 8.2 million tourists for the year 2010 [18]. A number of new developments have been proposed and investment in heritage sectors has also increased significantly. This progress is viewed as an important achievement for Melaka and has been the core factor for new development of the area.

Although engulfed with controversial issues of modern development within the historic core, the state government is steadfast in their effort to modernise the 
historic city. The construction of massive high rise, mixed use development is seen as the reason for the decline of heritage values of the historic buildings and has overshadowed the significance of the historic areas. The state government has formed the State Heritage Board in order to look after heritage and conservation to ensure the sustainability of historic buildings in Melaka.

However, although the historic buildings are protected under the acts and well cared for, excessive development activities surrounding the historic core may become the reason for the degradation of the historic values of the area, and thus may cause a loss of income for the tourism industry.

\subsection{Regeneration of George Town, Penang}

The social based approach to regeneration of George Town is designed to produce a multiplier effect for the economic development of the area. The vision is 'to provide better life to the locals, thus create better facilities for the tourists' [15]. The project targets enhancement, beautification and upgrading of infrastructure, pavements, street furniture and building facades.

Comprehensive development approaches by the municipality have enhanced the whole area making it worthy of representing the United Nation's criterion (iii) of outstanding universal value: living testimony to the multi-cultural heritage and tradition of Asia, and European colonial influences. This multicultural tangible and intangible heritage is expressed in the great variety of religious buildings of different faiths, ethnic quarters, the many languages, worship and religious festivals, dances, costumes, art and music, food, and daily life [19].

The Penang City Council has designed six major projects in the 'Draft Design Guidelines for Conservation Areas for the Inner City of George Town' (1987), which aim to give back the space to people following the principle of Local Agenda 21, 'the principles of sustainable development and the goal of ensuring a better quality of life for everyone, both now and in the future' [15, 20-22]. An urban regeneration scheme has been proposed using an all-inclusive approach, by considering the effect of the scheme to the local economy, identity and society. The proposal for the conservation of the historic area was based on the studies and technical exchange programme between the council and experts from Yokohama, Japan and Germany [23].

The first project for Lebuh Campbell (Campbell Street) started in 1986 and completed ten years later. The project focused on the traffic management throughout the area, the beautification and pedestrianisation of the street, modelled and designed after the famous Motomachi Mall in Yokohama [15, 23]. Another five projects were Beach Street, Lebuh Armenian-Lebuh Acheh, Little India, the Gold Bazaar and Penang Upper Road. The success of the Campbell Street project has convinced the local people to participate in the regeneration of the historic core of Penang, resulting in a shorter completion period for new projects - from ten years to nine months. This has prompted the federal and state governments to fund the rest of the project, and it is the beginning of a brighter future for conservation practices in Malaysia. 


\subsection{The conservation process}

Conservation awareness at Federal level led to the amendment of the Town and Country Planning Act (TCPA) in 1995 to give more emphasis and to add specific provision for the conservation of historic areas in the development plan [23]. The TCPA 1976, on which various conservation policies have been based, was found to be inadequate. Therefore, an amendment was made to provide more comprehensive powers regarding historic sites. In 2005, the Malaysian cabinet agreed to sanction the National Heritage Act 2005 (NHA 2005), which has no specific recognition of architectural heritage, but treats urban heritage in the wider context of cultural and historic significance [20].

\subsubsection{Conservation in the development schemes of Melaka}

Development within the historic core of Melaka has to follow the guidelines found under the Historic Area Action Plan 2006 based on the Melaka Enactment 1988 and the Town and Country Planning Act 1995 (Rev) Act A933) and the new Special Area Plan: the Conservation Area Management Plan of Melaka Historic City (2010) which was prepared according to subsection 16B (1), 2 and 3 Town and Country Planning Act 1976 [24, 25].

In order to retain the value of the city as a World Heritage Site, developments within the site have to comply with the guidelines of the World Heritage Organisation to ensure the sustainability of the World Heritage Sites. The Special Area Plan 2010 which encompasses the Conservation Management Plan for the Melaka Historic City was produced to be used as a guideline for the development agendas in Melaka, which include the regeneration schemes.

The vision of the Plan is 'to generate a suitable development, a safe and calm city to live in, with the basic needs, preserve the historical heritage and consult the stakeholder...' [25] which demonstrates the important relationship between regeneration and heritage with the environment, social activities and the economy of the area. Nonetheless, although it is all written very well on paper, it remains to be seen whether the vision can or will be executed in practice.

To support the conservation and protection of historic buildings in the city, the Federal government, under the Ministry of Information, Communication and Culture allocated RM30 million for the work in the year 2009 [16]. Conservation activities in the historic core of Melaka involved preservation, adaptive reuse and building and minor restoration. The unique characteristic of the historic core, which has been the administrative zone for different governments at different phases, has made the historic buildings within its compound suitable to be adapted to new uses, as commercial buildings, where the main tourism activities take place.

\subsubsection{Conserving historic George Town}

In Penang, the awareness of the value of heritage buildings in the urban development of George Town has been long realised. In 1974, the Interim Zoning Plans 1/73 were introduced by the former City Council of George Town as their first comprehensive land-use zoning plan for the city [21]. The plan aimed at preventing the destruction and deterioration of the historic part of the 
city. The Conservation Plan drew attention to the importance of maintaining the social and historical environment within the inner city. The concept plan was predicated on the following:

- Development of an urban centre linked to the major highway system.

- Restoration and rehabilitation of historic parts of the city.

- Definition of areas for private commercial and mixed development (to be maintained at moderate density).

- $\quad$ New areas for housing and integrated industry.

- $\quad$ Reserved areas for future development to cope with expansion.

- Maintenance of residential zones and existing character.

- $\quad$ Re-study of metropolitan limits.

In the State's 1987 Structure Plan, the guidelines regarding heritage buildings were included under the 1976 Antiquity Act. The plan spelled out a new planning management system that considers the strict control of development, incentives for the preservation of heritage buildings, preservation of ancient monuments and comprehensive planning and management for each conservation area. It was a turning point regarding the protection of historic buildings and was the basis for the formation of the Draft Design Guidelines for Conservation Areas 1987, and the implementation of these guidelines has safeguarded the heritage areas of George Town.

Nevertheless, the enactment of the State Structure Plan in 2007 provided general principles and policies for new development and interventions. It particularly emphasizes the need for conservation with strict measures for development control on sites identified for World Heritage Listing. It includes specific policies for the George Town Heritage Preservation Area.

\subsection{The Rent Control Act}

Another very powerful issue regarding conservation of historic buildings and urban conservation in Penang is the Rent Control Act 1966. The Rent Control Act 1966 or formerly Control of Rent Ordinance 1956 is a successful measure that has been safeguarding the built heritage in George Town for over half a century. The Act was introduced to protect tenants from huge rent increases because of the post-war housing shortage and to prevent owners from redeveloping their properties, thus it helps in preserving the old buildings [20, $21,23,26]$. However, in reality, it has contributed to the deterioration of the buildings because of lack of care and maintenance.

In 1997 the 1966 act was suspended and in January 2000, the act was finally repealed. Allegedly, residents are being evicted to make way for a multi-million tourism development planned for the historic core [26]. Since the UNESCO listing, a number of residents have been forced to vacate their premises to make way for businesses such as boutique hotels, pubs and restaurants [27]. Terrace house residents in historic quarters like Armenian Street, Carnarvon Street, Beach Street, Campbell Street and Steward Lane were forced to vacate their houses by their landlords who plan to commercialise their property into profit 
making businesses. The interests of tourism and the attraction of tourist dollars, along with the desire for modern living have contributed to this gentrification.

The end of the 1966 act also marks the beginning of intensive conservation and renovation works to some of the historic properties, and also a beginning of a renewed interest in giving George Town a transformation. Consequently, this has also contributed to the gentrification and change in character of the site, where the shophouses have undergone extreme transformation to adapt them to new uses, as happened in Melaka [21]. Fortunately, the Penang Structure Plan 2020 acknowledges the adaptive reuse of these traditional shophouses as essential to George Town's regeneration and economic growth. Therefore, conservation works regarding the historic buildings should comply with the policies of George Town Inner City Conservation Area Guidelines. Yet, the success of the implementation of the guidelines is still to be seen and its level of contribution to the conservation and regeneration schemes of George Town.

\subsection{Matters for inquiry}

The change of use from town hall to offices, warehouses to museums and government offices are characteristics of the redevelopment scheme of Melaka. Meanwhile, beautiful, eclectic shophouses, mostly located in the Historical Residential and Commercial Zone, remain as residential buildings on the upper levels and business premises on the ground floor. Some are used as budget hotels, motels or backpackers hostels. The change of use of the buildings is in accordance with the guidelines of the authority. Although it has helped the area to prosper by introducing new economic means, it has also interrupted the historic settings by introducing gentrification to the site, due to population and demographic changes to the character of the site.

The majority of local residents, mostly the younger generations, have moved out to give way to the changes taking place, transforming the ambience of the heritage area from a domestic residential area, to a commercial one. Like Melaka, Penang is experiencing growth in land values and home prices. Derelict shophouses in George Town, needing major conservation work, valued at RM 100,000 before July 2008, experienced quadruple increments after receiving the World Heritage Site status [15]. Nonetheless, the increase in value of the shophouses and real estate in George Town has prompted the State Government to intervene regarding the ownership of the properties. Foreigners, mostly Singaporean, are the main buyers of the old shophouses, foreseeing the rise in their value over time. To keep things local, the government was able to buy a number of shophouses to retain their ownership. This is to ensure that any changes or renovation made to the buildings would still retain their historic characteristics, as required by UNESCO, to maintain the World Heritage Site status.

There are, however, no specific acts that prevent foreign buyers from buying property in the historic areas in Malaysia [25]. This concern is acknowledged in Section 7.7 of Special Area Plan Melaka. The authority proposed two alternative mechanisms to strengthen the local ownership, with the aim of the restricting 
changes of ownership and selling of historic premises to foreign nationals. The mechanisms proposed are:

- Restriction in the land grant: Research by the registrar for lands and mines on the possibilities of stating in the grant of the land status as a part of a World Heritage Site that any buying and selling should go through the State Authority.

- Special purchase through the heritage fund: The State welcomes any selling of their land or premises to the State Government as 'right of first refusal' (ROFR). The transaction will be made through the Heritage Trust Fund using the concept of 'willing buyer- willing seller' through a memorandum of understanding.

- Other alternatives are exemptions from stamp duty and legal costs.

Nevertheless, the fate of the historic built environment in Malaysia is not assured. The short term benefit of heritage sales was seen as a profitable solution by some of the owners, regardless of the government initiatives to safeguard the heritage; it is a dispute between money and cultural nostalgia, a universal case where money often wins.

The approaches to regeneration, both in historic George Town and Melaka Town demonstrate the meaning of regeneration and urban heritage conservation in the Malaysian perspective. George Town, being a residential and institutional area, focuses on the development of spiritual and cultural life and infrastructure for the residents. Meanwhile, the historic core of Melaka represents a historic, administrative area focused on heritage tourism development.

Although the regeneration schemes of the two cities appear to be different, the goals are the same: to introduce new means for economic activities which will help to revive the area, in the form of heritage tourism and improvements to public facilities. Nonetheless, it remains to be seen whether this approach will be successful either in sustaining the heritage of the site or in providing a better life for the residents.

\section{References}

[1] Roberts, P. and Sykes, H. E. (2002). Urban Regeneration: A Handbook. London: Sage

[2] Jones, P. and Evans, J. (2008). Urban Regeneration in the UK. London: Sage.

[3] English Heritage (2008). Conservation Principles: Policies and Guidance; for the sustainable management of the historic environment. English Heritage.

[4] Mason, R. (2002). Assessing Values in Conservation Planning: Methodological Issues and Choices. In: De la Torre, M., ed. Assessing the Values of Cultural Heritage. Los Angeles: The Getty Conservation Institute.

[5] Smith, L. (2006). Uses of Heritage. Oxford: Routledge. 
[6] Lowenthal, D. (1985). The Past is a Foreign Country. Cambridge: Cambridge University Press.

[7] ICOMOS (1994). The Nara Documents on Authenticity. Nara, Japan: ICOMOS.

[8] Stovel, H. and Lemaire, R. (2008). Final Version: The Nara Documents of authenticity.

[9] Fielden, B. M. (2003). Conservation of Historic Buildings. 3rd ed. Oxford: Elsevier

[10] Larkham, P. (1996). Conservation and the City. London: Routledge.

[11] Izadi, M. (2008). A Study on City Centre Regeneration: a comparative analysis of two different apporaches to the revitalisation of historic city centres in Iran. Doctor of Philosophy. Newcastle University.

[12] Gunay, Z (2012) Historic Landscapes of Exclusion in Istanbul: Right to the city? In $15^{\text {th }}$ International Planning History Society Conference, Sao Paulo, Brazil, 15-18 July 2012.

[13] Licciardi, G. (2010). Supporting Sustainable Development in Historic Cities and Cultural Heriatge Sites. The World Bank.

[14] Shamsuddin, S. and Sulaiman, A. B. (2002). The Importance of Conserving the Old Town Centre in Achieving a Sustainable Built Environment of the Future. In: National Seminar on Built Environment: Sustainability through Management and Technology. Kuala Lumpur, 5th6th August 2002.

[15] Mohd Sharif, M. (2010). Personal communication 9 March 2010. George Town World Heritage Office General Manager.

[16] Ahmad, A. G. (2010). Personal Communication 30 April 2010. Deputy Commisioner of Heritage Malaysia.

[17] Khoo, S. N. (1993). Streets of George Town Penang. An illustrated guide to Penang's city streets and historic attractions. Penang, Malaysia: Janus Print and Resources.

[18] Government of Melaka (2010). Tourist Arrival statistic. [Online].

[19] UN (2008). Melaka and George Town, Historic Cities of the Straits of Malacca. Available at: http://whc.unesco.org/en/list/1223

[20] Lee, L. K., Lim, Y. K. and Yusuf, N. A. (2008). Strategies for urban conservation: A case example of George Town, Penang. Habitat International 32 (3), pp. 293-304.

[21] Penang. State Government (2008). Heritage Management Plan. George Town.

[22] UN (1992). Earth Summit- Local Agenda 21 Rio de Jeneiro: Available at: http://www.un.org/esa/earthsummit/

[23] Tan, T. S. (2002). Heritage Conservation Effort in George Town, Penang (Malaysia). In: World Heritage 2002: Shared Legacy, Common Responsibility, Associated Workshop. Urbino. Pesaro, Italy, 11-12 November 2002. UN.

[24] Melaka. Majlis Bandaraya Melaka Bersejarah (2006). Pelan Tindakan Kawasan Pemeliharaan Majlis Bandaraya Melaka Bandaraya Bersejarah. Melaka: MBMB. 
[25] Melaka. Majlis Bandaraya Melaka Bersejarah (2010). Special Area Plan: Conservation Area Management Plan of Melaka Historical City. Melaka: Majlis Bandaraya Melaka Bersejarah.

[26] Jenkins, G. and King, V. T. (2003). Heritage and development in Malaysian City: George Town under Threat? Indonesia \& the Malay World 31 (89), p.44.

[27] Bhatt, H. (2009). All brick and no soul. The Sun, 8 January 2009. 